\title{
Stress in pacu exposed to ammonia in water
}

\author{
Janessa Sampaio de Abreu ${ }^{1^{*}}$, Fábio Resende Esteves ${ }^{2}$, Elisabeth Criscuolo Urbinati ${ }^{2}$
}

\footnotetext{
${ }^{1}$ Centro de Aquicultura da UNESP - CAUNESP, Via de Acesso Prof. Paulo Donato Castelane, 14884-900, Jaboticabal, São Paulo, Brasil.

2 Universidade Estadual Paulista - UNESP, Faculdade de Ciências Agrárias e Veterinárias, Via de Acesso Prof. Paulo Donato Castelane, 14884-900, Jaboticabal, São Paulo, Brasil.
}

\begin{abstract}
The present study evaluated stress indicators in pacu exposed to ammonia in water under the following conditions: without $\mathrm{NH}_{4} \mathrm{Cl}(0.00 \mathrm{~g} / \mathrm{L})$; with $0.0078 \mathrm{~g} \mathrm{NH}_{4} \mathrm{Cl} / \mathrm{L}$; and with $0.078 \mathrm{~g} \mathrm{NH}_{4} \mathrm{Cl} / \mathrm{L}\left(\mathrm{pH} 8.3\right.$ and $\left.27{ }^{\circ} \mathrm{C}\right)$. After the salt dilution the water flow was interrupted and reestablished in 24 hours. Sampling occurred prior to the addition of $\mathrm{NH}_{4} \mathrm{Cl}(\mathrm{control})$ and after 12, 24 and 48 hours. Glycaemia increased only in fish with the highest salt concentration when compared with group control, regardless of time, and at 24 hours, regardless of treatment. Plasma ammonia, highest in fish exposed to the highest $\mathrm{NH}_{4} \mathrm{Cl}$ concentration, decreased progressively up to 48 hours. Plasma chloride only decreased in fish not exposed to salt when compared with control and osmolality increased after 24 hours. Hematocrit (Ht), number and volume of erythrocytes and hemoglobin did not change when $\mathrm{NH}_{4} \mathrm{Cl}$ was added; Ht decrease was reported after 12 hours, but it was not followed by the other blood parameters. The results show tolerance of the pacu to ammonia in the environment.
\end{abstract}

Key Words: cortisol, fish farming, fish physiology, Piaractus mesopotamicus, plasmatic ammonia, water quality

\section{Introduction}

With the fish farming intensification, several factors involved in the fish handling, such as water quality deterioration, may affect the biological homeostasis of fish, leading to reduction of their immunological resistance and higher susceptibility to environmental pathogens (Wendelaar Bonga, 1997). The concentration of nitrogenated residues, especially ammonia and nitrite, is a determinant factor in the water quality of the rearing environment. Ammonia may be found as ammonium ion $\left(\mathrm{NH}_{4}^{+}\right)$, slightly toxic to fish, and as $\mathrm{NH}_{3}$, which may reach toxic concentrations in inappropriately managed intensive systems (Randall \& Tsui, 2002). The $\mathrm{NH}_{3}$ concentration increases in high pH (Emerson et al., 1975). In high-density farming systems, the toxicity of total ammonia may be reduced by metabolically produced $\mathrm{CO}_{2}$, which decreases the $\mathrm{pH}$ of the water (Colt \& Orwicz, 1991).

A high level of ammonia in the water reduces the excretion of plasma ammonia in fish, fosters the $\mathrm{NH}_{3}$ absorption from the environment and increases body ammonia (Tomasso, 1994). The increase of ammonia in the blood (and of intracell $\mathrm{pH}$ ) changes several physiological functions, altering fish behavior, decreasing its growth and survival (Israeli-Weinstein \& Kimmel, 1998) and increasing fish susceptibility to diseases (Berka, 1986; Wendelaar Bonga, 1997). As a stressor, ammonia causes hormone, metabolic, ionic and hematological responses which are characteristic of the stress condition (Tomasso, 1994).

Although pacu (Piaractus mesopotamicus) is one of the most important native species in the Brazilian fish culture (Urbinati et al., 2010), few studies have demonstrated its stress responses related to farming procedures (Krieger et al., 1989; Martins et al., 2000; Takahashi et al., 2006; Biller et al., 2008). The present study evaluated the effects of ammonia exposure on stress (metabolic, hematological and ionic) indicators of pacu (Piaractus mesopotamicus) when ammonium chloride $\left(\mathrm{NH}_{4} \mathrm{Cl}\right)$ was added to the water.

\section{Material and Methods}

Eighty-one juvenile pacu (Piaractus mesopotamicus), with initial mean weight $279.8 \pm 48.9 \mathrm{~g}$, obtained by hormone-induced spawning of mature captive broodstock were used. Fish were randomly distributed in nine $100 \mathrm{~L}$ water tanks (9 fish/tank), with constant water flow and aeration, and fed a commercial diet (28\% crude protein) during the adaptation period of 15 days, when all fish were feeding normally. Fish were then exposed to the following $\mathrm{NH}_{4} \mathrm{Cl}$ (Merck, Germânia) concentrations after 24 h without feed: control - without the addition of $\mathrm{NH}_{4} \mathrm{Cl}$ in the water $(0.00 \mathrm{~g} / \mathrm{L})$; with the addition of $0.0078 \mathrm{~g} \mathrm{NH}_{4} \mathrm{Cl} / \mathrm{L}$ in the water; with the addition of $0.078 \mathrm{~g} \mathrm{NH}_{4} \mathrm{Cl} / \mathrm{L}$ in the water (three repetitions each). Total ammonia concentrations in 
the water were controlled by $\mathrm{NH}_{4} \mathrm{Cl}$ dilution (Table 1 ) under $\mathrm{pH} 8.3$ and water temperature at $27^{\circ} \mathrm{C}$. the $\mathrm{NH}_{4} \mathrm{Cl}$ amounts were defined according to studies with matrinxã (Brycon cephalus) (Alexandrino et al., 2002), tambaqui (Colossoma macropomum) and acará-açu (Astronotus ocellatus) (Marcon et al., 2004).

When salt was added, the water flow was interrupted and $0.5 \mathrm{~L}$ of water was taken from each tank to dilute the respective salt concentration according to the treatments. The solution was then gradually added to the tanks and only the aeration was maintained. The system remained static without water renewal for 24 hours. Fish were neither fed nor subjected to any management procedure (such as siphoning for tank cleansing) during this period. The same procedure was undertaken with the control treatment, without $\mathrm{NH}_{4} \mathrm{Cl}$ addition. Water flow was reestablished after 24 hours. Water samples were collected before salt addition, immediately after and 12, 24 and 48 hours after, and $\mathrm{pH}$ and temperature (pH Tecnopon mPA210), dissolved oxygen (SI 55 Yellow Springs Instruments) and total ammonia (TA) (Nessler's reagent solution) were evaluated. Non-ionized ammonia (NIA) was calculated according to Emerson et al. (1975).

Fish were sampled prior to the addition of salt (control group), and after 12, 24 and $48 \mathrm{~h}$. Six animals from each treatment $(n=6)$ were anaesthetized (Benzocaine, $66 \mathrm{mg} / \mathrm{L}$ of water) and bled at each sampling time, with EDTA, to determine blood glucose concentration (King \& Garner, 1947), hemoglobin, haematocrit, total number and mean corpuscular volume of the erythrocytes (apparatus Celm DA-500) and with sodium fluoride to separate plasma and determine chloride concentration (kit Labtest) and osmolality (Osmômetro Wescor 505). Another blood aliquot with sodium fluoride was de-proteinized with trichloroacetic acid $20 \%$ to determine total plasma ammonia (Verdow et al., 1977).

A completely randomized design was employed in a factorial arrangement, with 3 treatments (ammonia concentrations) and 3 sampling times as factors, plus the initial condition (control fish) and three repetitions. Data were analyzed with ANOVA and means compared by Tukey's test at 5\% significance using SAS (Statistical Analysis System, version 8.0). Results were expressed by mean \pm standard error of the mean.

Table 1 - Non-ionized $\left(\mathrm{NH}_{3}\right)$ and total $\left(\mathrm{NH}_{3}+\mathrm{NH}_{4}{ }^{+}\right)$ammonia and $\mathrm{NH}_{4} \mathrm{Cl}$ added to water at $27{ }^{\circ} \mathrm{C}$ and $\mathrm{pH} 8.3$

\begin{tabular}{lccc}
\hline $\mathrm{NH}_{4} \mathrm{Cl}(\mathrm{g} / \mathrm{L})$ & $\mathrm{NH}_{3}(\mathrm{mg} / \mathrm{L})$ & $\mathrm{NH}_{3}+\mathrm{NH}_{4}^{+}(\mathrm{mg} / \mathrm{L})$ & $\mathrm{NH}_{4} \mathrm{Cl}(\mathrm{g} / \mathrm{L})$ \\
\hline 0.0078 & 0.30 & 2.63 & 0.0078 \\
0.078 & 3.00 & 26.30 & 0.0780 \\
\hline
\end{tabular}

\section{Results and Discussion}

The addition of ammonium chloride to the water reproduced alterations in the ammonia levels which may occur in the fish farming practice. No significant interaction occurred between treatments and sampling periods regarding the evaluated physiological parameters. Concentrations of total ammonia and non-ionized ammonia increased soon after the dissolution of 0.0078 and $0.078 \mathrm{~g}$ $\mathrm{NH}_{4} \mathrm{Cl} / \mathrm{L}$ in the water and remained high until 24 hours (2.48 and $25.2 \mathrm{mg} / \mathrm{L}$ and 0.07 and $0.76 \mathrm{mg} / \mathrm{L}$, respectively). The tanks had constant aeration during this period, but with interrupted water flow (static system), which contributed to keep the total ammonia and non-ionized ammonia at high levels. After $48 \mathrm{~h}$, the water flow in the tanks was reestablished and total ammonia levels returned to the levels registered before the addition of the salt $(0.44 ; 0.49$ and $0.44 \mathrm{mg} / \mathrm{L}$ at $0.00 \mathrm{~g} ; 0.0078 \mathrm{~g}$ and $0.078 \mathrm{~g} \mathrm{NH}_{4} \mathrm{Cl} / \mathrm{L}$, respectively) (Figure 1A), whereas the non-ionized ammonia levels were lower than the initial levels (0.003; 0.004 and $0.003 \mathrm{mg} / \mathrm{L}$ at $0.00 \mathrm{~g} ; 0.0078 \mathrm{~g}$ and $0.078 \mathrm{~g} \mathrm{NH}_{4} \mathrm{Cl} / \mathrm{L}$, respectively) (Figure 1B). The other water quality parameters, such as dissolved oxygen, $\mathrm{pH}$ and temperature (Table 2) remained within the adequate levels for tropical fish (Boyd, 1981).

Immediately after adding $\mathrm{NH}_{4} \mathrm{Cl}$ to water, the nonionized ammonia concentrations at $0.0078 \mathrm{~g}$ and $0.078 \mathrm{~g}$ $\mathrm{NH}_{4} \mathrm{Cl} / \mathrm{L}$ (0.09 and $0.79 \mathrm{mg} / \mathrm{L}$, respectively) were higher than the concentration adequate for the farming of tropical fish species, whose desired levels are less than $0.025 \mathrm{mg} / \mathrm{L}$
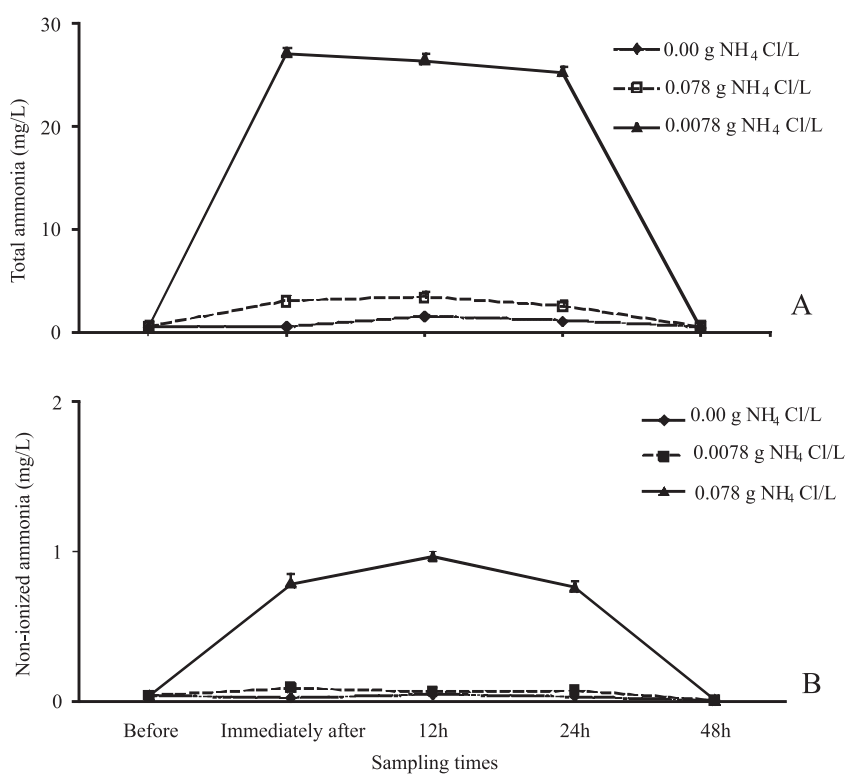

Figure 1 - (A) Total ammonia and (B) non-ionized ammonia levels of water before, immediately after, 12, 24 and 48 hours after addition of $\mathrm{NH}_{4} \mathrm{Cl}$. 
(Boyd, 1981). The total ammonia concentrations with this amount of non-ionized ammonia oscillate between $19.6 \mathrm{mg} / \mathrm{L}\left(\mathrm{pH} 7.0 ; 5^{\circ} \mathrm{C}\right)$ and $0.12 \mathrm{mg} / \mathrm{L}\left(\mathrm{pH} 8.5 ; 30^{\circ} \mathrm{C}\right)$ (Alabaster \& Lloyd, 1982). When the water flow was reestablished at 24 hours, fish were still exposed to high non-ionized ammonia concentrations $(0.07$ and $0.76 \mathrm{mg} / \mathrm{L}$, respectively, for $0.0078 \mathrm{~g}$ and $\left.0.078 \mathrm{~g} \mathrm{NH}_{4} \mathrm{Cl} / \mathrm{L}\right)$. Total and non-ionized ammonia increased (1.05 and $0.03 \mathrm{mg} / \mathrm{L}$, respectively) in the group without $\mathrm{NH}_{4} \mathrm{Cl}$, probably due to the ammonia excreted by fish and accumulated in the water. At 48 hours the content of total ammonia returned to level which is adequate to the species $(0.44 \mathrm{mg} / \mathrm{L})$ due to the water renewal in the tanks, whereas the non-ionized ammonia levels were lower (approximately $0.004 \mathrm{mg} / \mathrm{L}$ ) than the initial ones $(0.04 \mathrm{mg} / \mathrm{L})$, probably due to the decrease in $\mathrm{pH}$.

Stress caused by ammonia rise in the environment may increase disease incidence and mortality, impairs performance (Berka, 1986; Wendelaar Bonga, 1997), changes fish behavior (Israeli-Weinstein \& Kimmel, 1998) and influences other stress indicators (Fivelstad et al., 1993). In fact, few studies have evaluated the effects of ammonia on Brazilian native species. Marcon et al. (2004) calculated the lethal concentration of non-ionized ammonia $\left(\mathrm{CL}_{50}\right)$ for two species of Amazon fish, Colossoma macropomum (tambaqui) (0.69 $\mathrm{mg} \mathrm{NH}_{3} / \mathrm{L}$ ) and Astronotus ocellatus (acará-açu) (2.01 $\mathrm{mg} \mathrm{NH}_{3} / \mathrm{L}$ ). The studies concluded that both species were highly tolerant to this form of ammonia when compared with other tropical fish species. Juveniles of pirarucu, Arapaima gigas, were also highly tolerant to ammonia when exposed to increasing concentrations of ammonia in the water (2.0 $\mathrm{mg} \mathrm{NH}_{3} / \mathrm{L}$ ) (Cavero et al., 2004). Information on ammonia levels in pacu farming is restricted to investigations in which total and non-ionized ammonia concentrations maintained themselves within amounts recommended for tropical fish (Urbinati et al., 2010). Behavior alterations or mortality were not reported during the experimental period in the present study, in contrast to that reported by Israeli-Weinstein \& Kimmel (1998) for Cyprinus carpio exposed to sub-lethal ammonia concentrations. These authors verified that $\mathrm{NH}_{4} \mathrm{Cl}$-treated fish ignored feeding and dive to the bottom of the tank, remaining there for a certain period of time. This behavior was interpreted either as an exhaustion response and an attempt to save energy needed to overcome the stress condition or an adaptive strategy: waiting for conditions to improve. According to these authors, in high ammonia concentration, the fish slowly reach the water surface, probably due to gill damage or as a result of mucus accumulation and show hyperglycemia. The present study shows that $24 \mathrm{~h}$ after salt addition to water there was an increase in blood glucose (Figure 2) in fish of all treatments $(\mathrm{P}<0.05)$, whereas fish exposed to high ammonium chloride concentration $(0.078 \mathrm{~g} / \mathrm{L})$ presented higher glycaemia $(\mathrm{P}<0.05)$ when compared with the control ones. Although the blood glucose level of the pacu exposed to a high ammonia concentration $(58.3 \mathrm{mg} / \mathrm{dL})$ is higher than that in fish prior to the exposure $(42.0 \mathrm{mg} / \mathrm{dL})$, glucose levels do not indicate stress conditions as occurred in pacu (Takahashi et al., 2006), matrinxã (Brycon amazonicus; Urbinati et al., 2004), jundiá (Rhamdia quelen; Barcellos et al., 2001), tambaqui (Colossoma macropomum; Gomes et al., 2003a) and pirarucu (Arapaima gigas; Gomes et al., 2003b). The increase in glycaemic levels in these fish species after the application of the stress factor was higher (40 to $50 \mathrm{mg} / \mathrm{dL}$ in basal condition for 70 to $250 \mathrm{mg} / \mathrm{dL}$ after the stressing factor) than

Table 2 - Dissolved oxygen, $\mathrm{pH}$ and temperature of water before, immediately after, 12, 24 and 48 hours after addition of $\mathrm{NH}_{4} \mathrm{Cl}$

\begin{tabular}{|c|c|c|c|c|}
\hline & & Dissolved $\mathrm{O}_{2}(\mathrm{mg} / \mathrm{L})$ & $\mathrm{pH}$ & $\mathrm{T}\left({ }^{\circ} \mathrm{C}\right)$ \\
\hline Before & $\begin{array}{l}0.00 \mathrm{~g} \mathrm{NH}_{4} \mathrm{Cl} / \mathrm{L} \\
0.0078 \mathrm{~g} \mathrm{NH}_{4} \mathrm{Cl} / \mathrm{L} \\
0.078 \mathrm{~g} \mathrm{NH}_{4} \mathrm{Cl} / \mathrm{L}\end{array}$ & $\begin{array}{l}5.46 \pm 0.04 \\
5.39 \pm 0.10 \\
5.65 \pm 0.10\end{array}$ & $\begin{array}{l}8.14 \pm 0.02 \\
8.11 \pm 0.03 \\
8.19 \pm 0.01\end{array}$ & $\begin{array}{l}26.93 \pm 0.09 \\
26.97 \pm 0.12 \\
26.93 \pm 0.03\end{array}$ \\
\hline Immediately after & $\begin{array}{l}0.00 \mathrm{~g} \mathrm{NH}_{4} \mathrm{Cl} / \mathrm{L} \\
0.0078 \mathrm{~g} \mathrm{NH}_{4} \mathrm{Cl} / \mathrm{L} \\
0.078 \mathrm{~g} \mathrm{NH}_{4} \mathrm{Cl} / \mathrm{L}\end{array}$ & $\begin{array}{l}5.03 \pm 0.03 \\
4.72 \pm 0.10 \\
5.35 \pm 0.24\end{array}$ & $\begin{array}{l}7.79 \pm 0.02 \\
7.68 \pm 0.02 \\
7.46 \pm 0.23\end{array}$ & $\begin{array}{l}26.03 \pm 0.03 \\
26.00 \pm 0.12 \\
26.00 \pm 0.06\end{array}$ \\
\hline 12 hours & $\begin{array}{l}0.00 \mathrm{~g} \mathrm{NH}_{4} \mathrm{Cl} / \mathrm{L} \\
0.0078 \mathrm{~g} \mathrm{NH}_{4} \mathrm{Cl} / \mathrm{L} \\
0.078 \mathrm{~g} \mathrm{NH}_{4} \mathrm{Cl} / \mathrm{L}\end{array}$ & $\begin{array}{l}4.77 \pm 0.05 \\
3.76 \pm 0.59 \\
5.38 \pm 0.07\end{array}$ & $\begin{array}{l}7.74 \pm 0.04 \\
7.57 \pm 0.09 \\
7.86 \pm 0.02\end{array}$ & $\begin{array}{l}24.17 \pm 0.43 \\
23.70 \pm 0.15 \\
23.90 \pm 0.25\end{array}$ \\
\hline 24 hours & $\begin{array}{l}0.00 \mathrm{~g} \mathrm{NH}_{4} \mathrm{Cl} / \mathrm{L} \\
0.0078 \mathrm{~g} \mathrm{NH}_{4} \mathrm{Cl} / \mathrm{L} \\
0.078 \mathrm{~g} \mathrm{NH}_{4} \mathrm{Cl} / \mathrm{L}\end{array}$ & $\begin{array}{l}5.55 \pm 0.27 \\
6.08 \pm 0.13 \\
5.96 \pm 0.09\end{array}$ & $\begin{array}{l}7.77 \pm 0.06 \\
7.81 \pm 0.04 \\
7.83 \pm 0.01\end{array}$ & $\begin{array}{l}21.90 \pm 0.20 \\
21.60 \pm 0.25 \\
22.17 \pm 0.42\end{array}$ \\
\hline 48 hours & $\begin{array}{l}0.00 \mathrm{~g} \mathrm{NH}_{4} \mathrm{Cl} / \mathrm{L} \\
0.0078 \mathrm{~g} \mathrm{NH}_{4} \mathrm{Cl} / \mathrm{L} \\
0.078 \mathrm{~g} \mathrm{NH}_{4} \mathrm{Cl} / \mathrm{L}\end{array}$ & $\begin{array}{l}4.98 \pm 0.03 \\
5.45 \pm 0.09 \\
5.13 \pm 0.07\end{array}$ & $\begin{array}{l}7.09 \pm 0.00 \\
7.09 \pm 0.01 \\
7.09 \pm 0.00\end{array}$ & $\begin{array}{l}26.73 \pm 0.03 \\
26.57 \pm 0.12 \\
26.60 \pm 0.06\end{array}$ \\
\hline
\end{tabular}

Water samplings prior to blood collection.

Results in mean \pm mean standard error.

$\mathrm{T}$ - temperature. 
that recorded in the present research. When matrinxã were exposed to ammonia concentrations higher than those of the present study ( 0.2 and $\left.0.4 \mathrm{~g} \mathrm{NH}_{4} \mathrm{Cl} / \mathrm{L}\right)$, the blood glucose increased one hour after salt addition in the group exposed to higher concentrations when compared with those in group control ( 97.7 and $55.9 \mathrm{mg} / \mathrm{dL}$, respectively) (Alexandrino et al., 2002).

Plasma ammonia decreased gradually until $48 \mathrm{~h}$ after the $\mathrm{NH}_{4} \mathrm{CL}$ addition, with difference $(\mathrm{P}<0.05)$ between the 12 and 48 hours samplings, higher $(\mathrm{P}<0.05)$ in fish exposed to higher concentration of ammonia in the water (Figure 3 ). The decrease at $48 \mathrm{~h}$ was due to the water renewal, return of the environmental total ammonia to adequate levels for the species and the elimination of the body ammonia. Cavero et al. (2004) reported a positive relationship between an increase of ammonia concentration in the water and

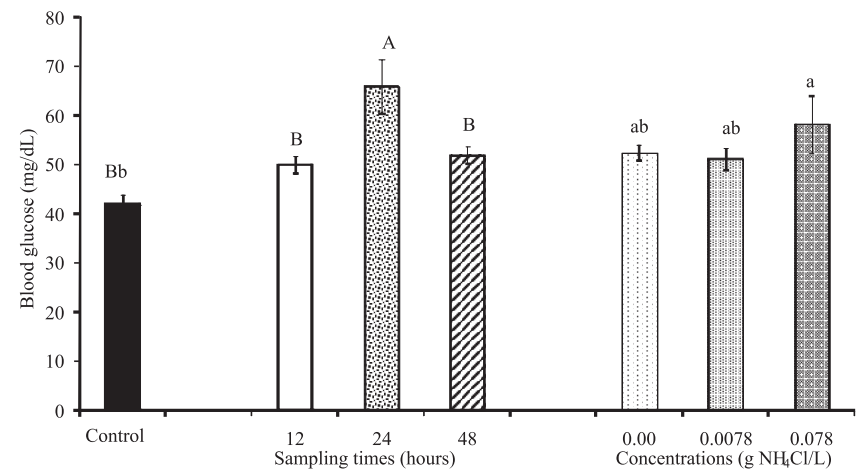

Means followed by similar capital letters between sampling periods (means of all treatments are shown on the same bar) and by small letters between treatments (means of all sampling periods represented on the same bar) do not differ.

Figure 2 - Blood glucose (mg/dL) of pacu (Piaractus mesopotamicus) before (control), 12, 24 and 48 hours after exposure to $\mathrm{NH}_{4} \mathrm{Cl}$.

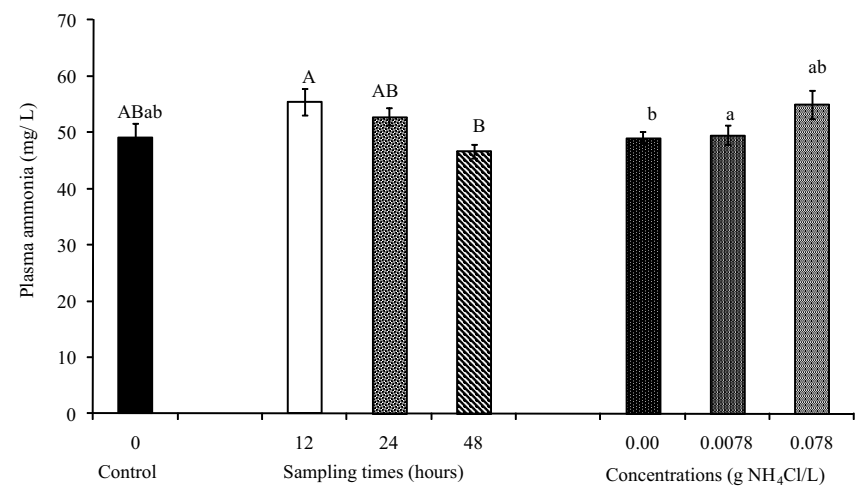

Means followed by the same capital letters between sampling periods (means of all treatments are shown on the same bar) and by lowercase letters between treatments (means of all sampling periods represented on the same bar) do not differ.

Figure 3 - Plasma ammonia in pacu (Piaractus mesopotamicus) before (control), 12, 24 and 48 hours after exposure to $\mathrm{NH}_{4} \mathrm{Cl}$. the increase of plasma ammonia in pirarucu juveniles (Arapaima gigas) exposed for 33 days to increasing concentrations $(0,5,10,15,20$ and $25 \mathrm{mg} / \mathrm{L})$ of total ammonia in the environment. The highest concentration to which pirarucu were exposed was approximately $25 \mathrm{mg}$ of total ammonia/L, as in the present study. Plasma glucose in the pirarucu decreased as the water ammonia concentration increased, suggesting that the species is tolerant to high concentrations of ammonia in the water. According to these authors, since the species inhabits preferentially the shallow lakes of the Amazon, which undergo extreme oxygen conditions and high levels of nitrogenous compounds at certain periods of the year, it developed strategies which tolerate environmental adversities, such as aerial respiration, which makes it resistant to low levels of dissolved oxygen. These authors also suggest that the species has a physiological mechanism to metabolize ammonia when it is exposed to high concentrations of the ion.

The plasma chloride $(\mathrm{P}<0.05)$ levels decreased in pacu not exposed to $\mathrm{NH}_{4} \mathrm{Cl}$ when compared with control (Figure 4A), and osmolality $(\mathrm{P}<0.05)$ increased as of $24 \mathrm{~h}$ compared with the $12 \mathrm{~h}$ sampling (Figure 4B). During the
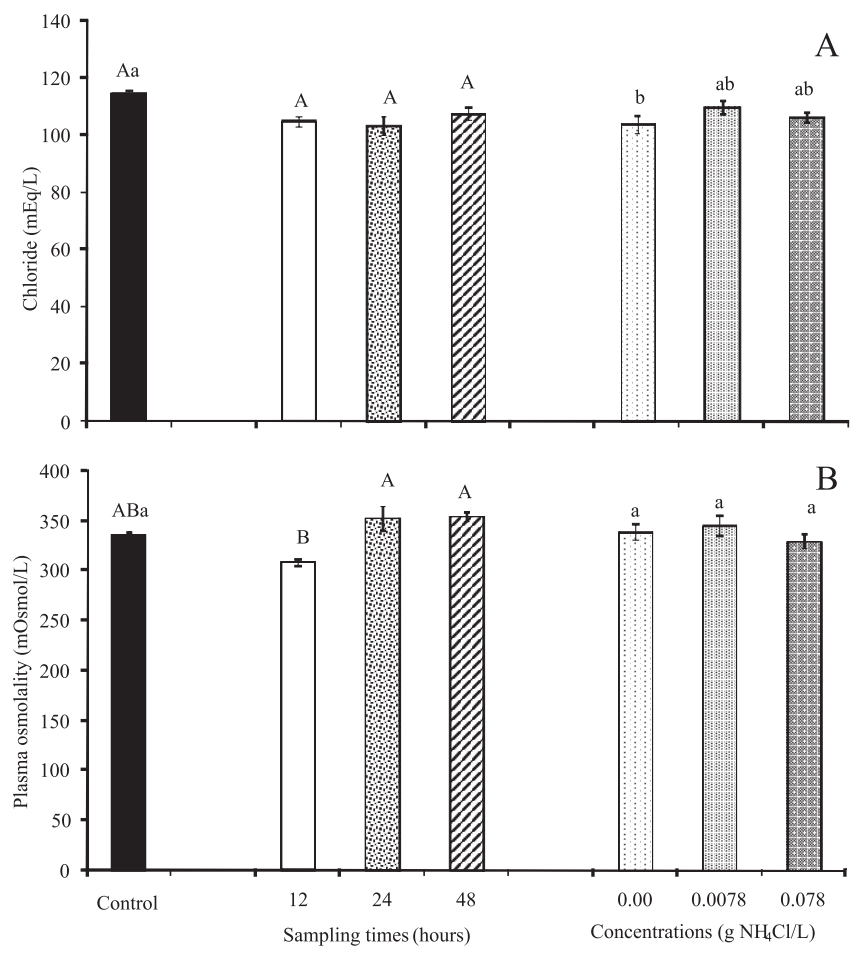

Means followed by the same capital letters between sampling periods (means of all treatments are shown on the same bar) and by lowercase letters between treatments (means of all sampling periods represented on the same bar) do not differ.

Figure 4 - Chloride (A) and plasma osmolality (B) in pacu (Piaractus mesopotamicus) before (control), 12, 24 and 48 hours after exposure to $\mathrm{NH}_{4} \mathrm{Cl}$. 
stress responses, there is increase of permeability of the gills, through the action of catecholamine, with losses mainly of sodium and chlorite ions and osmoregulatory
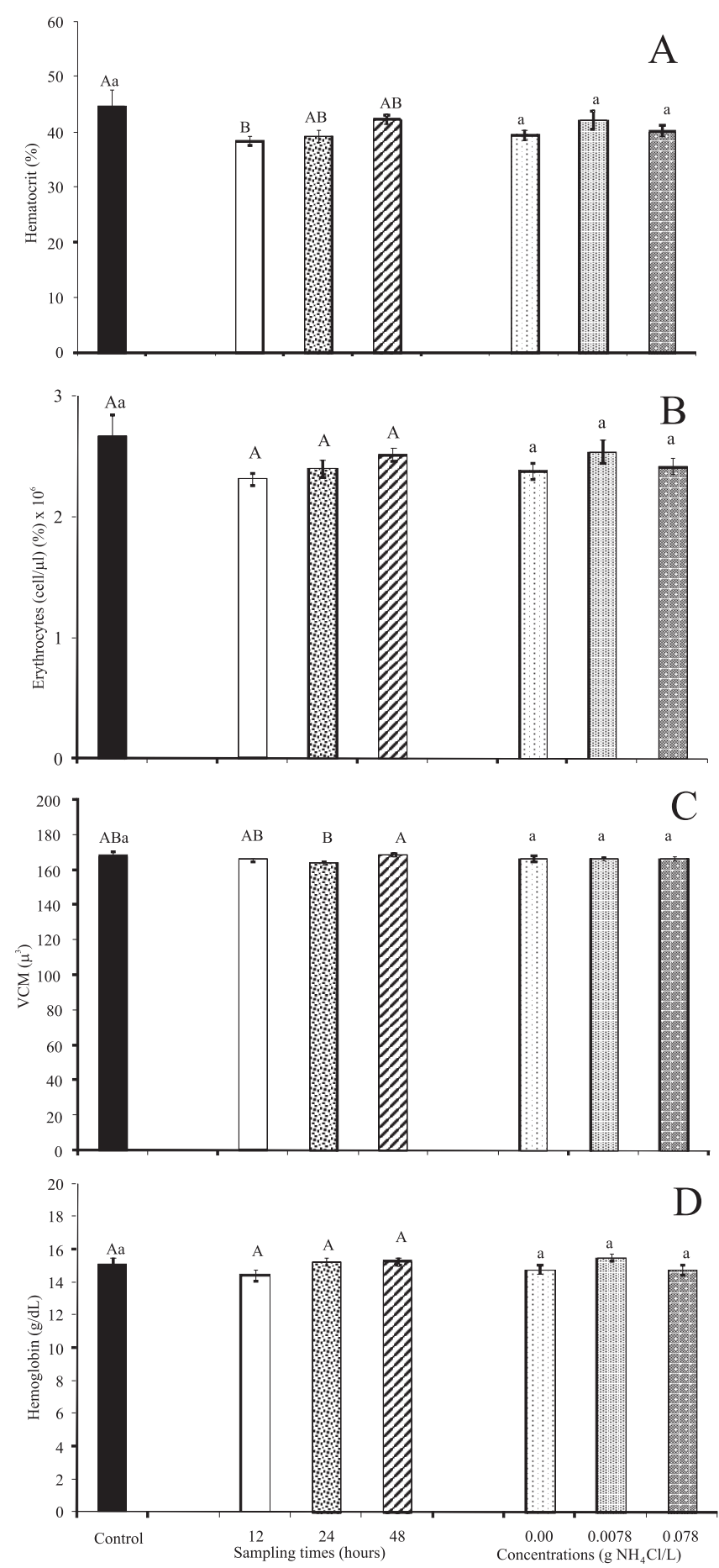

Means followed by the same capital letters between sampling periods (means of all treatments are shown on the same bar) and by lowercase letters between treatments (means of all sampling periods represented on the same bar) do not differ.

Figure 5 - Hematocrit (A), number of erythrocytes (B), mean corpuscular volume (VCM, C) and hemoglobin (D) in pacu (Piaractus mesopotamicus) before (control), 12, 24 and 48 hours after exposure to $\mathrm{NH}_{4} \mathrm{Cl}$. disorders (McDonald \& Milligan, 1997). However, no changes in the chloride profile and plasma osmolality that could be related to ammonia exposure were reported.

Alterations in the hematological parameters that would indicate stress conditions did not occur (Figure 5). The hematocrit decreased $(\mathrm{P}<0.05) 12 \mathrm{~h}$ after salt addition, regardless of the ammonia level in the water (Figure 5A). The mean corpuscular volume was not modified among levels of ammonia in the water $(\mathrm{P}>0.05)$ but was significantly higher in the $48 \mathrm{~h}$ sampling when compared with the $24 \mathrm{~h}$ value (Figure 5C). The number of erythrocytes (Figure 5B) and hemoglobin (Figure 5D) remained unchanged. Although changes in these parameters may reveal stress in fish (McDonald \& Milligan, 1997; Morgan \& Iwama, 1996, no changes were associated with ammonium chloride added to the water, stressing the absence of stress response of the other indicators discussed.

The present study suggests lack of stress responses during the exposure of the pacu to ammonia in concentrations $0.0078 \mathrm{~g}$ and $0.078 \mathrm{~g}$ of ammonia chloride for $24 \mathrm{~h}$. In spite of the fact that the pacu were exposed to levels of total ammonia (approximately 25mg total ammonia/L) above those normally adequate to tropical species, no mortality, behavior alteration or significant physiological alterations occurred under the experimental conditions of the present study (temperature, $\mathrm{pH}$ and exposure time).

\section{Conclusions}

Piaractus mesopotamicus juveniles are resistant to the environmental ammonia when exposed to it for 24 hours.

\section{Acknowledgements}

The authors would like to thank Mrs Damares Perecim Roviero for her support in the laboratory analyses and the Aquaculture Center of UNESP (CAUNESP) for the fish donation, logistic support and facilities.

\section{References}

ALABASTER, J.S.; LLOYD, R. Water quality criteria for freshwater fish. 2.ed. Cambridge: FAO, Butterworth Scientific, 1982. 361p.

ALEXANDRINO, B.; ROSATO, P.N.; GONÇALVES, F.D. et al. Indicadores de estresse em matrinxã (Brycon cephalus) exposto à diferentes concentrações de amônia. In: SIMPÓSIO BRASILEIRO DE AQÜICUlTURA, 12., 2002, Goiânia. Anais... Goiânia: Associação Brasileira de Aquicultura, 2002. p.279.

BARCELLOS, L.J.G.; WOEHL, V.M.; WASSERMANN, G.F. et al. Plasma levels of cortisol and glucose in response to capture and tank transference in Rhamdia quelen (Quoy \& Gaimard), a South American catfish. Aquaculture Research, v.32, p.121-123, 2001. 
BERKA, R. The transport of live fish. A review. Rome: FAO, 1986. 52p. (EIFAC Technical Papers, 48).

BILLER, J.D.; BENDHACK, F.; URBINATI, E.C. Stress responses in pacu juveniles (Piaractus mesopotamicus) submitted to repeated air exposure. Acta Scientiarum Animal Sciences, v.30, n.1, p.89-93, 2008.

BOYD, C.E. Water quality in warmwater fish culture. Auburn: Auburn University, 1981. 359p.

CAVERO, B.A.S.; FILHO, M.P.; BORDINHON, A.M. et al. Tolerância de juvenis de pirarucu ao aumento da concentração de amônia em ambiente confinado. Pesquisa Agropecuária Brasileira, v.29, n.5, p.513-516, 2004.

COLT, J.; ORWICZ, K. Modeling production capacity of aquatic culture systems under freshwater conditions. Aquaculture Engineering, v.10, p.1-29, 1991.

EMERSON, K.; RUSSO, R.C.; LUND, R.E. et al. Aqueous ammonia equilibrium calculations: effect of $\mathrm{pH}$ and temperature. Journal of the Fisheries Research Board of Canada, v.32, p.2379-2383, 1975.

FIVELSTAD, S.; KALLEVIK, H.; IVERSEN, H.M. et al. Sublethal effects of ammonia in smolts at a low temperature. Aquaculture International, v.1, p.157-169, 1993.

GOMES, L.C.; ARAUJO-LIMA, C.A.R.M.; ROUBACH, R. et al. Avaliação dos efeitos da adição de sal e da densidade no transporte de tambaqui. Pesquisa Agropecuária Brasileira, v.38, p.283-290, 2003a.

GOMES, L.C.; ROUBACH, R.; CAVERO, B.A.S. et al. Transport of pirarucu Arapaima gigas juveniles in plastic bag. Acta Amazonica, v.33, n.3, p.637-642, 2003b.

ISRAELI-WEINSTEIN, D.; KIMMEL, E. Behavioral response of carp Cyprinus carpio to ammonia stress. Aquaculture, v.165, p.81-93, 1998.

KING, E.J.; GARNER, R.J. Colorimetric determination of glucose. Journal of Clinical Pathology, v.1, p.30-33, 1947.

KRIEGER, M.H.A.; DELATTRE, E.; CAROLSFELD, J. et al. A timecourse study of physiological indicators of handling stress in the tropical fish Piaractus mesopotamicus (pacu). Brazilian Journal of Medical and Biological Research, v.22, p.1019-1022, 1989.
MARCON, J.L.; MOREIRA, S.S.; FIM, J.D.I. Median lethal concentration (LC50) for un-ionized ammonia in two Amazonian fish species, Colossoma macropomum and Astronotus ocellatus. In: INTERNATIONAL CONGRESS ON THE BIOLOGY OF FISH, 6., 2004, Manaus. Anais... Manaus, 2004. p.105-116.

MARTINS, M.L.; MORAES, F.R.; MORAES, J.R.E et al. Falha da resposta do cortisol ao estresse por captura e por carragenina em Piaractus mesopotamicus Holmberg, 1887 (Osteichthyes: Characidae). Acta Scientiarum, v.22, p.545-552, 2000.

McDONALD, G.; MILLIGAN, L. Ionic, osmotic and acid-base regulation in stress. In IWAMA, G.W.; PICKERING, A.D.; SUMPTER, J.P. et al. (Eds.). Fish stress and health in aquaculture. Cambridge: University Press, 1997. p.119-144.

MORGAN, J.D.; IWAMA, G.K. Cortisol-induced changes in oxygen consumption and ionic regulation in coastal cutthroat trout (Oncorhynchus clarki clarki) parr. Fish Physiology and Biochemistry, v.15, n.5, p.385-394, 1996.

RANDALL, D.J.; TSUI, T.K. Ammonia toxicity in fish. Marine Pollution Bulletin, v.45, n.1-12, p.17-23, 2002.

TAKAHASHI, L.S.; ABREU, J.S.; BILLER, J.D.et al. Efeito do ambiente pós-transporte na recuperação dos indicadores de estresse de pacus juvenis, Piaractus mesopotamicus. Acta Scientiarum Animal Sciences, v.28, p.469-475, 2006.

TOMASSO, J.R. Toxicity of nitrogenous wastes to aquaculture animals. Reviews in Fisheries Science, v.2, p.291-314, 1994.

URBINATI, E.C.; ABREU, J.S.; CAMARGO, A.C.S. et al. Loading and transport stress in juvenile matrinxã (Brycon cephalus) at various densities. Aquaculture, v.229, p.389-400, 2004.

URBINATI, E.C.; GONÇALVES, F.D.; TAKAHASHI, L.S. Pacu (Piaractus mesopotamicus). In: BALDISSEROTTO, B.; GOMES, L.C. (Eds.). Espécies nativas para piscicultura do Brasil. Santa Maria: Editora UFSM, 2010. p.205-244.

VERDOW, H.; ECTHTELD, C.J.A.; DEKKERS, E.M.J. Ammonia determination based on indophenol formation with sodium salicylate. Water Research, v.12, p.399-402, 1977.

WENDELAAR BONGA, S.E. The stress response in fish. Physiological Reviews, v.77, n.3, p.591-625, 1997. 